\title{
Benchmark for REIT Performance in Malaysia Using Hedonic Regression Model
}

\author{
Olusegun Olaopin Olanrele ${ }^{1}$, Rosli Said ${ }^{1} \&$ Mohd Nasir Daud ${ }^{1}$ \\ ${ }^{1}$ Department of Estate Management, Faculty of Built Environment, University of Malaya, Kuala Lumpur, \\ Malaysia \\ Correspondence: Olusegun Olaopin Olanrele, Department of Estate Management, Faculty of Built Environment, \\ University of Malaya, 50603 Kuala Lumpur, Malaysia. Tel: 601-9652-0401. E-mail: Olanrele@siswa.um.edu.my
}

Received: June 13, 2014

Accepted: June 24, 2014

Online Published: August 25, 2014

doi:10.5539/ijef.v6n9p165

URL: http://dx.doi.org/10.5539/ijef.v6n9p165

\begin{abstract}
This paper focuses on the setting of a benchmark for the REIT performance within the REIT industry to achieve a sector induced national REIT index for Malaysia. The study has as objectives to (i) explore literatures on performance and benchmarking; (2) appraise REIT performance analysis as presented in the past studies; and (3) propose Hedonic Regression Model analysis towards setting a benchmark for REIT. The study adopted the quantitative research and analysis method. Three conventional REITs were purposively selected to reflect diversity in portfolio and location. Data were extracted from the annual reports of Three (3) REIT companies (AmFirst REIT, Starhill REIT \& AmanahRaya REIT) through their websites for period of five years (20082012). Hedonic regression was performed on the collected data from the REITs Company to forecast benchmark for the REITs based on individual capacity as reflected by the economic and operational indices. Thereafter the average of the return forecast for the three selected REIT represents an aggregate benchmark for the REIT industry in Malaysia. The study found that the M-REIT do outperform the KLCI but performed lower than the industry set return for 2013 by the study. The limitation of the study is twofold, first the sample for the study is small ( 3 out of the 12 conventional REITs) and secondly the study did not cover the Islamic REIT and there are 3 Islamic REITs in Malaysia. The identified limitations will be addressed in future research.
\end{abstract}

Keywords: benchmark, hedonic model, performance, REIT

\section{Introduction}

Real Estate Investment Trust (REIT) performance can be literarily explained in terms of its operational success which is revealed in its profitability to the investors (Grupe \& DiRocco, 1999). In other words, success of an investment is determined by its profitability. REIT markets have proved extremely successful in United States of America (US) and Australia, with more growth expected in the REIT markets in Asia and in Europe (Hoesli \& Lizieri, 2007). The operations of Real Estate Investment Trusts (REITs) are tailored towards investing in income generating real estate assets, most especially commercial properties-office and retail properties. The recent trends however show that REITs funds are invested in healthcare and hospitality facilities as well as high rise income yielding residential properties, industrial and agricultural properties. In general, the performance of REITs is mainly determined by the different types of investments the companies make, which is basically divided into Equity REIT, Mortgage REIT and Hybrid REIT (which invest in both equity and mortgage debts) (Grupe \& DiRocco, 1999). Returns from REITs are primarily derived from rents from their property assets and capital appreciation and expresses in form of dividend. Dividend is thus a measure of performance of REIT as it is for any investment in the stock/capital market and could be measured in percentages (\%) or money units (e.g., cents or Ringgit).

In every investment performance studies, there is always a benchmark for comparison and decision. A study carried out on Arab Malaysian First Property Trust, First Malaysia Property Trust and AmanahHarta Tanah PNB was done to reflect the systematic risk and performance of these REIT companies compared to market risk ratios including Sharpe Index, Treynor Index, and Jensen Index within the time frame of Jan 1991 and Apr 1995. The study concluded that REIT are low-correlated with the market, which means they perform better than the market during the bearish phase, but they are opposite during the bullish market. Systematic risks in respect of the three REITs studied were high and the cause is traced to speculation as reported by the study. Newell, Ting, and 
Archeampong (2002) reported that AmanahHarta Tanah PNB is the only REIT, out of 4 other samples to outperform KLCI index and the Kuala Lumpur Properties Index for the period of 1991 till 2000 period (The study in effect used the KLCI and KLPI as bench mark). These indexes focused on the capital market elements and factors like return from the other forms of investment which are dictated or affected by a different set of factors/attributes from the factors that affect real estate property returns which in turn affects REIT returns and performance. While we acknowledge the past studies in their attempt on REIT performance, we identify a gap in the field of study in two perspectives. Firstly, none of the studies has consider the simultaneity effect of the contributing economic factors but rather study each factor in isolation of others (keeping other factors constant or assuming their non existence) and secondly, the benchmark of a purely market index which is solely dependent on share price movement in the stock exchange does not reflect the dynamism and heterogeneity characteristics of real estate asset and real property market which is a dominant factor to REIT return. We intend to fill this gaps and thus contribute to the existing body of knowledge. The study will also be useful to REIT investors and decision makers in identifying the contribution of each factor to the success of REIT operation for optimum performance decision.

\section{Background to the Study}

\subsection{History and Development of Malaysian REITs (M-REITS)}

REIT started in the United States in 1960. Since then more countries around the world have established REIT regimes at different times. The spread of the REIT approach to real estate investment around the world has also increased awareness and acceptance of investing in global real estate securities. REIT is not new in Malaysia, It was previously known as Property Trust Fund which had been in existence since 1989. Malaysian Property Trust Fund (PTF) was developed in line with the Australian Listed Property Trust (LPT) model as a basis to set up the regulatory framework (Ahmad \& Izah, 2010; Hwa, 2008). The Bank Negara Malaysia (Malaysian Central Bank) approved the first regulatory framework under Company Act 1965 and Securities Commission Act of 1983, governed the establishment and operations of the Property Trust Funds. The Securities Commission became regulator later on in 1991 and further guidelines were published by the Specific Securities Commission in 1995 (Ong, The, \& Chong, 2011). The Securities Commission introduced a consultation process for property related trust funds in 1999 which lead to a revised guideline in 2002. Malaysian REIT in modern form, came into existence in 2005 following the guidelines of the Securities Commission same year. This particular amendment stated that the minimum fund size is RM 100 million for REIT to be formed in Malaysia. The management company has entitlement to foreign effective equity, limited to the maximum of $70 \%$ (Ong et al., 2011)). Furthermore, real estate investment trust can either be listed or unlisted in Malaysian Stock Exchange. However, relevant listing and shareholding prerequisites issued by KLSE must be complied with by the listed REIT(s). According to the Finance Act 2004, real estate investment trusts are enabled to indulge the tax treatment as followed:

1) The undistributed income will be taxed at $28 \%$ while distributed income will be tax exempted.

2) The tax payable at $28 \%$ will be withheld by real estate investment trusts for non-residents.

3) Accumulated income that has been taxed and subsequently distributed is eligible for tax credit.

Besides, stamp duties are exempted on all transfer of real property for REITs as stated in the Finance Act 2004. Real property gains taxes are also exempted for property sale transaction from owners to REITs (Ahmad \& Izah, 2010).

Today, Malaysian REIT (M-REIT) has Fifteen (15) REITs companies out of which three (3) are Islamic REITs (Bursa Malaysia Securities, 2013). Following the Asian economic crisis of 1997, other Asia countries established REIT market with Japan pioneering the movement in 2001, followed by Singapore in 2002, Taiwan in 2004, and Hong Kong in 2005. In a comparison, Japan was found to have the most developed REIT market in Asia, while Singapore's REIT market appears to be the most dynamic. Arab Malaysia First Property Trust, being the pioneer of Malaysia listed REITs in September 1989, followed by First Malaysian Property Trust in Nov 1989 and AmanahHarta Tanah PNB in December 1990. The trend continues with the Axis Real Estate Investment Trust in July, 2005, Starhill Real Estate Investment Trust in December, 2005, and UOA Real Estate Investment Trust in December 2005. The several new REIT companies consist of Capital Mall Malaysian Trust, Sunway Real Estate Investment Trust, and Pavillion Real Estate Investment Trusts were introduced in 2010 (Table 1). 
Table 1. M-REITs types and their property portfolio

\begin{tabular}{lllll}
\hline S/N & Company Name & Acronym & Property portfolio type & Type of REIT \\
\hline 1 & AmanahRaya REIT & ARREIT & Office/hotel/industrial/education/hospital & Conventional \\
2 & Pavilion REIT & PAVREIT & Retail/Residential & Conventional \\
3 & Tower REIT & TWRREIT & Office & Conventional \\
4 & AmFirst REIT & AMFIRST & Office/retail/hotel & Conventional \\
5 & CapitalMalls Malaysia Trust & CMMT & Retail & Conventional \\
6 & AL-Hadharah Boustead REIT & BSDREIT & Plantation & Islamic \\
7 & IGB REIT & IGBREIT & Authorized investment & Conventional \\
8 & AL-Aqar Healthcare REIT & ALAQAR & Office/ healthcare/hotel & Islamic \\
9 & Starhill REITS & STAREIT & Residential/hotel/retail & Conventional \\
10 & Atrium REITS & ATRIUM & Warehouse/office & Conventional \\
11 & UOA REITS & UOAREIT & Office/Commercial & Conventional \\
12 & Hektar REIT & HEKTAR & Retail & Conventional \\
13 & Sunway REITS & SUNREIT & Diversified & Conventional \\
14 & Axis-REIT & AXREIT & Office/Industrial & Islamic \\
15 & Quill Capital Trust & QCAPITA & Office/Commercial/Industrial & Conventional \\
\hline
\end{tabular}

Source: Bursa Malaysia Securities, 2013-09.

\subsection{The Concept of REIT Performance and Benchmarking}

In accounting the rate of return (ROI) on capital invested is a measure of performance of a business (investment). The analysis of performance is then carried out through a variety of comparison with established yardstick (Oxley \& Smith, 1996) like ratio (Trynox, Sharpe, KLCI, CPI etc), Key Performance Index (KPI), or use of Balanced Score Card (BSC) or correlation analysis. The comparison of performance against established comparable or set yardstick is referred to as Benchmarking. This means the performance of identified comparable in term of return (mostly in percentages) is a benchmark/yardstick to measure and judge the performance of a subject investment. Benchmarking is seen as a means of identifying improvement opportunities as well as monitoring the performance of competitors (Young, 1993). Camp (1989) defines benchmarking as "the continuous process of measuring products, services and practices against the toughest competitor or those companies recognized as industry leaders, it is a search for industry best practices that leads to superior performance".

Benchmarking is a term originally used by Land Surveyors to compares elevations (Kouzmin, Loffler, Klages, \& Korac-Kakabadse, 1999). Horvath and Herter (1992) in same line with Camp (1989) defined benchmarking as a continuous systematic process of measuring products, services and practices against organizations regarded to be superior with the aim of rectifying any performance gaps. It aims at identifying competitive targets and establishes means of improvement. To measure portfolio performance, studies have traditionally employed performance measures that compare the returns of managed portfolio to the returns of a benchmark like S\&P500 index, NYSE Composite, NAREIT Index, Composite Price Index (CPI), KLCI, ASI, or compare the volatility of an investment with ratios like Jensen Measures, Treynox ratio, Sharpe ratio etc (Amidu, Aluko, Nuhu, \& Saibu, 2008; Grinblatt \& Titman, 1993). Newell et al. (2002) used KLCI \& KLPI as benchmark in their study for the period 1991 to 2000 and discovered that only AmanahHarta Tanah was the only REIT to outperform KLCI index and the KLPI. The question then arises here. Do these indices have the same economic and sociopolitical factors that affect their performance with REIT? Comparing REIT return which has much dependency on the income from property assets which in turn depend on economic, socio-demography, political and environmental factors with purely capital market determined index will not reflect true performance of REIT.

REIT performance analysis has been premised on benchmarking where the return from REITs is compared against market indices. The problem here is not of benchmarking but of the benchmark (e.g. KLCI or Sharpe ratio index). Various authors have considered effect or contribution of different factor attribute on REIT return (NAV, FFO, Size, Asset Value and Leverage) (Allen, Madura, \& Springer, 2000; Banz, 1981; Delcoure \& Dickens, 2004; Hamelink \& Hoesli, 2004; Keim, 1983; Lee \& Kau, 1987; Mclntosh, Liang, \& Tompkins, 1991; Olgun, 2005; Ratcliffe \& Dimowski, 2007). Though, studies on REIT return identified Net Asset Value (NAV), Fund from Operations (FFO), Leverage/Gearing, Capitalisation, Asset Value as well as external factors like Location as determinant of REITs performance (Alias \& Soi Tho, 2011; Brounen \& Sjoerd, 2012; Chaudhry, Maheshwari, \& Webb, 2004; Feng, Price, \& Sirmans, 2011; Gore \& Stott, 1998; Hamelink \& Hoesli, 2004; Hwa 
\& Abdul Rahman, 2007; Ong et al., 2011; Ting \& Mohd, 2007; Yong, Allen, \& Lim, 2009). These attributes were considered each in isolation of the other. The reality is that all the factors are acting simultaneously and should be so treated, as they have joint effect on return, therefore the application of hedonic model is expected to predict/forecast the REITs return in full consideration of the simultaneity effect of all the factors. Invariably any factor that affects property income affects REITs performance. The heterogeneity nature of the real estate assets alone is enough to accrue for a magnitude of differences in performance of REITs and other investment vehicles and this should be reflected in the performance measurement/analysis. While there is need for a yardstick to be set in REITs performance analysis, this study believed that such yardstick/benchmark is expected to be dictated or forecast by the workings of the determining factors of REITs return. Since it has been proved that REITs return depends on NAV, FFO, Size, Gearing and Asset Value amidst mixed findings, the relationship between these component factor determinants and REITs return should be established to make a more realistic forecast of a benchmark. In portfolio return analysis, the expected return is the average return of each investment over a defined time period, in the same vein the return of REITs and the corresponding values of the determinant factors over a period of time can be used for regression for a forecast. The Hedonic Price Model therefore provides a theoretical explanation for this study. The conviction is that a benchmark for REIT performance should be set by the forecast of return from REIT, based on past performance using hedonic regression. Therefore this study used the hedonic model regression to predict an expected return that could serve as benchmark of REIT return. If the actual return is lower, REIT is performing below its capacity and if return is higher, then REIT performance will be judged above expectation, a good result and a plus for REIT industry.

\subsection{Hedonic Price Model}

Hedonic analysis is the study of the relationship between price of a product and the characteristics of the product. People buy and use properties for the benefits, enjoyment and its services. Every property possesses certain attributes or characteristics that determine the price of a house. Such attributes will include land size, the space, age, services, facilities, management, parking lots and its location attributes such as unique position, accessibility to other places of interest and the neighbourhood. Each of these attributes affect the price people are willing to pay in order to occupy the property. Hedonic analysis in real estate investigates the relationship between the existence and the contributions of these attributes to price of a property (in terms of either rental or capital/sales value). These attributes can be observed for each transaction property along with their prices. Hedonic price model therefore find the combination method called "hedonic function" which uses attributes as inputs and forms the market price of a property as the output (Coulson \& Robin, 2001), $P=f\left(X_{1} \ldots X_{n}\right)$. With the hedonic function, it becomes easier to predict the price of property unit before it is sold. This is because hedonic analysis made it possible to observe the attributes and then estimates the contribution of each attribute to the overall price of a property. It is also used to create Housing Price Index across time and location.

Hedonic analysis of price occurs when researchers proposed methods that systematically used data on existing products to derive statistical relationship between real estate prices and real estate characteristics. Hedonic function is described to be a mathematic function form that links characteristics collectively defined as $\mathrm{X}$ to the price of the real estate product $P$. Therefore:

\section{Hedonic Price Function}

$$
\begin{gathered}
P=f(X) \text { or } P=f\left(X_{1} \ldots . X_{n}\right) \\
\text { where } X \text { ranges from } X_{1}, \ldots, X_{n}
\end{gathered}
$$

Making $\mathrm{f}(\mathrm{X})$ to be a linear function we have

$$
P=a_{o}+a_{1} X_{1}+a_{2} X_{2}+a_{3} X_{3}+\ldots+a_{n} X_{n}
$$

In the linear relation, using calculus differential equation,

$$
\partial P / \partial X_{1}=a_{1}
$$

A change in $P$ due to change in $X_{1}$ is constant and equal to $a_{1}$ (Green \& Malpezzi, 2001). Incorporating the chances of least square errors, the equation becomes

$$
P=a_{o}+a_{1} X_{1}+a_{2} X_{2}+a_{3} X_{3}+\ldots+a_{n} X_{n}+e .
$$

a linear regression line summarized as

$$
P=X a+e
$$

Where $X_{1} \ldots X_{n}$ are the attributes/characteristics of the property and $P$ is the price of the property. This is hedonic function. The function requires statistical procedure to calculate the values of $a_{s}$ which give the 
influence of each X on the price. Wallace (1926) used regression analysis to generate a model of farmland price. Court (1939) investigated the influence of quantities of characteristics such as Horsepower and Wheelbase on the prices of cars and was the first to use the term 'hedonic' for the method; his findings were corroborated by Goodman (1998). Sheppard (1999) cited Waugh (1929) as another early user of multivariate regression analysis to assess the contribution of characteristics to price for vegetables. The basic of hedonic regression is to consider a differentiated or heterogeneous commodity in which the characteristics of the product are fundamental to its value in the market place. The heterogeneity of commodities is particularly apparent in real estate market. Since hedonic regression has been accepted in the forecast of property prices, it seems logical that it can be used to forecast a benchmark for REIT performance since the underlying assets of a REIT is real property. It will also take into consideration the simultaneity effect of the factors that affect REIT performance.

\section{Methodology and Data Collection}

This study adopted quantitative research method and purposively selected three (3) REIT companies as sample out of fifteen, AmFirst REIT to represent the office/retail portfolio; Starhill REIT representing Residential/hospitality/retail portfolio and AmanahRaya REIT to represent Industrial/Educational/Hotel Portfolio. The purpose is to reflect the diversification in terms of properties in the portfolio in order to have adequate representation of the diversity. AmFirst REIT was established on 28th September, 2006 and listed on the main market of Bursa Malaysia Securities Berhad on 21st December, 2006. The company is one of the largest Malaysia based commercial REIT with office, retail and hotel properties in its portfolio consisting of a total of Nine (9) properties worth RM1.179billion. Starhill REIT was listed on the main market of Bursa Malaysia Securities Berhad on $16^{\text {th }}$ December, 2005. There are 13 properties in the portfolio of Starhill REIT with market capitalization of RM1.335billion and property classes including retail, Hospitality and residential. Starhill REIT also has international diversification with properties in Japan and Australia. In December, 2011 Strahill REIT was repositioned as a full fledge hospitality REIT with main focus on hotel and hospitality related assets. 96\% of Starhill REIT fund is invested in real estate assets and the remaining 4\% was invested in deposit with licensed financial institutions. AmanahRaya REIT was established on 10th October, 2006 and listed on the main market of Bursa Malaysia Securities Berhad on 26th February, 2007. As at December 31, 2012, the portfolio of AmanahRaya REIT comprises of Thirteen (13) properties spread across educational, retail, industrial and hotel properties. The total asset value of properties in AmanahRaya REIT portfolio is RM1.046billion. The REIT companies were listed on the main market (Board) of the Bursa Malaysia Securities Berhad between December 2005 and February, 2007. The data were collected from 2008 to 2012 showing that the data reflected full year annual returns of the REIT companies in the sample for the period regardless of each company's financial year.

Quantitative data relating to the factor attributes/variables affecting REIT return were collected from secondary source, the annual report of the REIT companies through their individual website (table 2).

Table 2. Extracted data from the annual report of the REIT companies (2008-2012)

\begin{tabular}{|c|c|c|c|c|c|c|c|c|c|}
\hline Conpany & Year & $\begin{array}{l}\text { Units } \\
\text { (million) }\end{array}$ & $\begin{array}{l}\text { Price } \\
(\mathrm{RM})\end{array}$ & $\begin{array}{l}\text { NAV } \\
(\mathrm{RM})\end{array}$ & $\begin{array}{l}\text { Capitalisation } \\
(\mathrm{RM})\end{array}$ & $\begin{array}{l}\text { FFO } \\
\text { (RM'm) }\end{array}$ & $\begin{array}{l}\text { Leverage } \\
\left(\mathrm{RM} \mathrm{M}^{\prime} \mathrm{m}\right)\end{array}$ & $\begin{array}{l}\text { Asset Value } \\
(\text { RM'm) }\end{array}$ & $\begin{array}{l}\text { Dividend } \\
\text { (Sen) }\end{array}$ \\
\hline AmFirst REIT & 2008 & 429.001 & 0.89 & 1.03 & 381.81089 & 31.313 & 396.6 & 836 & 7.3 \\
\hline \multirow[t]{4}{*}{$\mathrm{IPO}=\mathrm{RM} 1$} & 2009 & 429.001 & 0.87 & 1.325 & 373.23087 & 37.537 & 402 & 980 & 8.75 \\
\hline & 2010 & 429.001 & 0.85 & 1.3535 & 364.65085 & 41.915 & 413 & 1,008 & 9.75 \\
\hline & 2011 & 429.001 & 1.1 & 1.3631 & 471.9011 & 41.75 & 407 & 1,024 & 9.75 \\
\hline & 2012 & 429.001 & 1.16 & 1.3917 & 497.64116 & 39.994 & 550 & $1,179.84$ & 9.31 \\
\hline AmanahRaya REIT & 2008 & 431.553191 & 0.73 & 1.0198 & 315.0338294 & 67.066 & 253 & 686.332 & 7.0105 \\
\hline \multirow[t]{4}{*}{$\mathrm{IPO}=\mathrm{M} 0.94$} & 2009 & 431.553191 & 0.885 & 1.0198 & 381.924574 & 30.877 & 253 & 686.332 & 7.1549 \\
\hline & 2010 & 573.219858 & 0.935 & 0.9744 & 535.9605672 & 41.401 & 362.9653 & 913.617 & 7.4398 \\
\hline & 2011 & 573.219858 & 0.91 & 1.0496 & 521.6300708 & 73.692 & 363.2607 & 944.76 & 7.22 \\
\hline & 2012 & 573.219858 & 0.92 & 1.0586 & 527.3622694 & 46.887 & 363.5561 & 952.476982 & 7.4487 \\
\hline Starhill REIT & 2008 & 1178.888889 & 0.9 & 1.1878 & 1061 & 20.104 & 180 & $1,529.66$ & 6.8936 \\
\hline \multirow[t]{4}{*}{$\mathrm{IPO}=\mathrm{RM} 0.9$} & 2009 & 1178.888889 & 0.855 & 1.1662 & 1007.95 & 18.268 & 0 & $1,550.33$ & 6.65 \\
\hline & 2010 & 1178.888889 & 0.88 & 1.1508 & 1037.422222 & 13.538 & 180 & 494.7 & 5.72 \\
\hline & 2011 & 1324.888889 & 0.885 & 1.1443 & 1172.526667 & 51.62 & 180 & $1,611.51$ & 7.23 \\
\hline & 2012 & 1324.888889 & 1.03 & 1.1165 & 1364.635556 & 16.81 & $1,489.43$ & $1,570.41$ & 6.32 \\
\hline
\end{tabular}

Source: websites of AMFirst REIT, AmanahRaya REIT and Starhill REIT). 


\section{Data Analysis, Result and Discussion}

In line with the requirement for a valid multiple regression in statistics, necessary test were performed on the data in respect of multiple regression assumptions of (i)Normality of the distribution of data, (ii) Correlation among the variables, (iii) Linearity, (iv) Outliers and (v) Heretoskedasticity. The normality test was done through the statistics for skewness and kurtosis. All the variables except loan/leverage are normally distributed with values greater than -1.96 and less than +1.96 , the normal distribution range. Loan/leverage has a higher value for both the skewness and kurtosis and shows that loan/leverage is not normally distributed suggesting it to be outlier (table 3 ).

Table 3. Statistics for normal distribution test

\begin{tabular}{lllllll}
\hline & Net Asset Value & Size & Net Property Income & Loan & Asset Value & Dividend \\
\hline $\mathrm{N} \quad$ Valid & 15 & 15 & 15 & 14 & 15 & 15 \\
& \multicolumn{1}{c}{ Missing } & 0 & 0 & 0 & 1 & 0 \\
Mean & 1.1567 & 667.6454 & 38.1848 & 413.8437 & 1064.5312 & 7.5965 \\
Std. Deviation & .14031 & 352.51004 & 17.48545 & 328.09189 & 353.08886 & 1.22565 \\
Skewness & .558 & .854 & .506 & 3.049 & .369 & .727 \\
Std. Error of Skewness & .580 & .580 & .580 & .597 & .580 & .580 \\
Kurtosis & -1.088 & -.886 & -.041 & 10.407 & -.887 & -.375 \\
Std. Error of Kurtosis & 1.121 & 1.121 & 1.121 & 1.154 & 1.121 \\
\hline
\end{tabular}

A further test for outliners using the Mahalanobis distance test shows that there is no outlier in the data with a maximum value of 11.465 (Table 4) which is less than the maximum value of 20.52 for a regression involving 5 independent variables. Therefore we decided not to consider loan as an outlier.

Table 4. Residuals statistics for outliers

\begin{tabular}{llllll}
\hline & Minimum & Maximum & Mean & Std. Deviation & $\mathrm{N}$ \\
\hline Predicted Value & 5.7373 & 9.5244 & 7.6641 & 1.19658 & 14 \\
Std. Predicted Value & -1.610 & 1.555 & .000 & 1.000 & 14 \\
Standard Error of Predicted Value & .149 & .421 & .268 & .082 & 14 \\
Adjusted Predicted Value & 6.3798 & 9.6168 & 7.8540 & 1.08493 & 14 \\
Residual & -.45240 & .60757 & .00000 & .33487 & 14 \\
Std. Residual & -1.060 & 1.423 & .000 & .784 & 14 \\
Stud. Residual & -1.463 & 1.621 & -.075 & .988 & 14 \\
Deleted Residual & -1.76623 & .78846 & -.18988 & .72045 & 14 \\
Stud. Deleted Residual & -1.599 & 1.851 & -.058 & 1.051 & 14 \\
Mahal. Distance & .652 & 11.465 & 4.643 & 3.500 & 14 \\
Cook's Distance & .001 & 2.782 & .322 & .724 & 14 \\
Centered Leverage Value & .050 & .903 & .357 & .269 & 14 \\
\hline
\end{tabular}

Pearson correlation test indicated that there is no autocorrelation among all the variables with all correlation values less than 0.9 (Table 5). To confirm the validity of regression, a test of hoteroskedascticity using the Bruesch- Pegan F-test and White's chi square $\left(\chi^{2}\right)$ test. The $F$ statistics of the regression is 19.961 greater than $F$ value $(3.482)$ and significant at $\mathrm{P}<0.05$. The White's LM $\chi^{2}$ statistics is 13.75 greater than the $\chi^{2}$ value (11.07) and also significant at $\mathrm{P}<0.05$. The statistics confirm that the regression is free from heteroskedasticity. The scatter plot of the residual is in fig 1 showing no identified pattern of distribution and suggested that the residual of the predicted variable is not affected by the independent variables. 


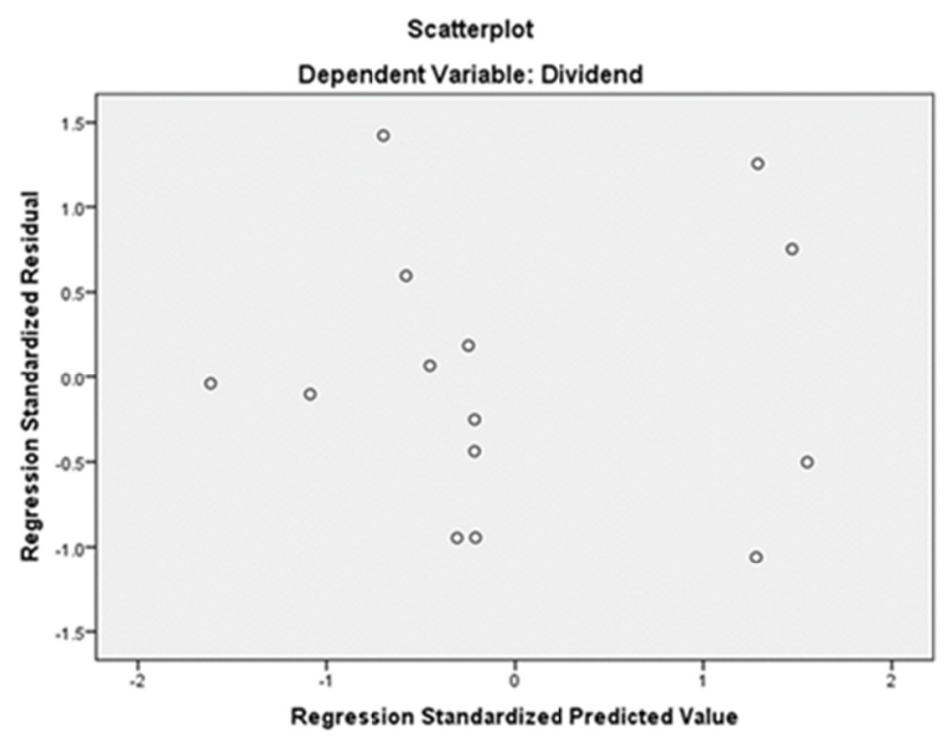

Figure 1. Scater plot of the regression residual

Table 5. Correlations among the variables

\begin{tabular}{|c|c|c|c|c|c|c|c|}
\hline & & Net Asset Value & Size & Net Property Income & Loan & Asset Value & Dividend \\
\hline Net Asset & Pearson Correlation & 1 & -.048 & -.159 & .077 & .249 & $.732^{* *}$ \\
\hline \multirow[t]{2}{*}{ Value } & Sig. (2-tailed) & & .864 & .572 & .793 & .3771 & .002 \\
\hline & $\mathrm{N}$ & 15 & 15 & 15 & 14 & 15 & 15 \\
\hline \multirow[t]{3}{*}{ Size } & Pearson Correlation & -.048 & 1 & $-.533^{*}$ & .375 & $.664^{* *}$ & $-.588^{*}$ \\
\hline & Sig. (2-tailed) & .864 & & .041 & .186 & .0007 & .021 \\
\hline & $\mathrm{N}$ & 15 & 15 & 15 & 14 & 15 & 15 \\
\hline Net Property & Pearson Correlation & -.159 & $-.533^{*}$ & 1 & -.295 & -.230 & .305 \\
\hline \multirow[t]{2}{*}{ Income } & Sig. (2-tailed) & .572 & .041 & & .306 & .409 & .270 \\
\hline & $\mathrm{N}$ & 15 & 15 & 15 & 14 & 15 & 15 \\
\hline \multirow[t]{3}{*}{ Loan } & Pearson Correlation & .077 & .375 & -.295 & 1 & .417 & -.052 \\
\hline & Sig. (2-tailed) & .793 & .186 & .306 & & .138 & .860 \\
\hline & $\mathrm{N}$ & 14 & 14 & 14 & 14 & 14 & 14 \\
\hline \multirow[t]{3}{*}{ Asset Value } & Pearson Correlation & .249 & $.664^{* *}$ & -.230 & .417 & 1 & -.022 \\
\hline & Sig. (2-tailed) & .371 & .007 & .409 & .138 & & .939 \\
\hline & $\mathrm{N}$ & 15 & 15 & 15 & 14 & 15 & 15 \\
\hline \multirow[t]{3}{*}{ Dividend } & Pearson Correlation & $.732^{* *}$ & $-.588^{*}$ & .305 & -.052 & -.022 & 1 \\
\hline & Sig. (2-tailed) & .002 & .021 & .270 & .860 & .939 & \\
\hline & $\mathrm{N}$ & 15 & 15 & 15 & 14 & 15 & 15 \\
\hline
\end{tabular}

Note. ${ }^{* *}$. Correlation is significant at the 0.01 level (2-tailed). *. Correlation is significant at the 0.05 level (2-tailed).

The Normal P-P plot shows the linearity curve of the regression (Figure 2). The data satisfy all the assumption of multiple regression analysis. 


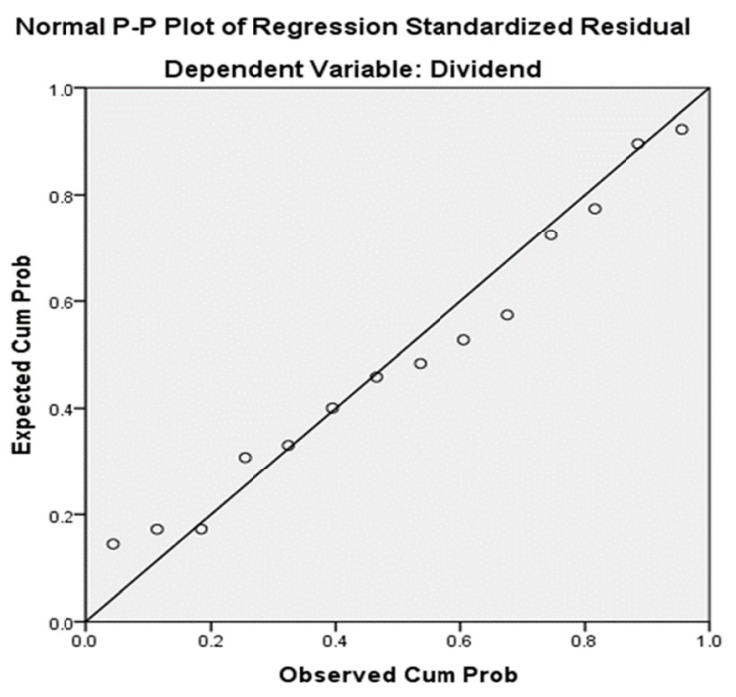

Figure 2. Linearity curve of regression

The data in Table 2 were entered into the computer software SPSS for regression analysis following the Hedonic price index model. The regression return the intercept $\alpha_{0}$ and beta $\beta_{1-n}$ values and the equation read thus:

$$
\mathrm{D}=1.349+5.565 \mathrm{~N}-0.002 \mathrm{~S}+0.007 \mathrm{I}+0.000367 \mathrm{~L}+0.001 \mathrm{~V}
$$

where $\mathrm{D}$ is dividend, $\mathrm{N}$ is $\mathrm{NAV}, \mathrm{S}$ is Size, $\mathrm{I}$ is FFO, $\mathrm{L}$ is leverage and $\mathrm{V}$ is asset value (Table 3).

Table 6. Regression coefficients

\begin{tabular}{|c|c|c|c|c|c|c|}
\hline & \multirow{2}{*}{ Model } & \multicolumn{2}{|c|}{ unstandardised coefficients } & \multirow{2}{*}{ Sig. } & \multicolumn{2}{|c|}{$95.0 \%$ Confidence Interval for B } \\
\hline & & $\mathrm{B}$ & Std. Error & & Lower Bound & Upper Bound \\
\hline \multirow{6}{*}{1} & (Constant) & 1.349 & 1.261 & .313 & -1.504 & 4.202 \\
\hline & Net Asset Value & 5.565 & .956 & .000 & 3.402 & 7.729 \\
\hline & Capitalisation & -.002 & .001 & .002 & -.004 & -.001 \\
\hline & Net Income & .007 & .009 & .411 & -.012 & .027 \\
\hline & Loan & .000 & .000 & .358 & .000 & .001 \\
\hline & Asset Value & .001 & .001 & .094 & .000 & .002 \\
\hline
\end{tabular}

Note. a. Dependent Variable: Dividend.

At $\mathrm{P} \leq 0.05$, Two of the independent variables have significant contribution to yield. These are NAV and size (0.000253 and 0.002 respectively). FFO, Loan and Asset value have insignificant contribution (0.313. 0.411 and 0.094 respectively. The model summary shows that all the listed independent variables jointly contribute $91.7 \%$ to dividend with $\mathrm{R}$ square value of 0.917 . This means other factors that were not considered in this study contributes $8.3 \%$ to dividend. Having $\mathrm{P}$ value of 0.000125 , the contribution of the five considered independent variables to dividend is significant at $\mathrm{P} \leq 0.05$ (Table 7).

Table 7. Regression model summary

\begin{tabular}{|c|c|c|c|c|c|c|c|}
\hline \multirow{2}{*}{ Model } & \multirow{2}{*}{$\mathrm{R}$} & \multirow{2}{*}{ R Square } & \multicolumn{5}{|c|}{ Change Statistics } \\
\hline & & & R Square Change & F Change & df1 & df2 & Sig. F Change \\
\hline 1 & $.958^{\mathrm{a}}$ & .917 & .917 & 19.961 & 5 & 9 & .000125 \\
\hline
\end{tabular}

Note. a. Predictors: (Constant), Asset Value, Net Income, Net Asset Value, Loan, Capitalisation.

The residual of regression is 1.74 and mean square error of 0.193 , the allowable error at $95 \%$ confidence level is 1.96, therefore the regression is validated at 1.74 which is less than 1.96 (Table 8). The F statisics of 19.961 is greater than F critical value on statistical table (3.482), therefore we reject the unstated hypothesis that the 
independent variables does not have significant simultaneous effect on dividend. We therefore concluded in affirmation of the simultaneity of all factor determinants of REIT return.

Table 8. Analysis of variance (ANOVA)

\begin{tabular}{lllllll}
\hline Model & & Sum of Squares & Df & Mean Square & F & Sig. \\
\hline \multirow{3}{*}{1} & Regression & 19.292 & 5 & 3.858 & 19.961 & $.000^{\mathrm{b}}$ \\
& Residual & 1.740 & 9 & .193 & & \\
& Total & 21.031 & 14 & & & \\
\hline
\end{tabular}

Note. a. Dependent Variable: Dividend. b. Predictors: (Constant), Asset Value, Net Income, Net Asset Value, Loan, Capitalisation.

The regression equation was fixed with the real values of the independent variables and a new set of predicted dividend for each year (for each REIT Company) was calculated. The predicted dividend for each year is slightly higher than the amount of dividend declared by the companies (Table 9). The average of the predicted vale 7.78 Sen $(8.52 \%)$ is presented as benchmark for REIT performance in Malaysia. This is higher than the average return of $6.26 \%$ declared by Bursa Malaysia for September 2013.

Table 9. Predicted dividend and yield

\begin{tabular}{|c|c|c|c|c|c|c|c|c|c|}
\hline Conpany & Year & $\begin{array}{l}\text { NAV } \\
(\mathrm{RM})\end{array}$ & $\begin{array}{l}\text { Capitalisation } \\
(\mathrm{RM})\end{array}$ & $\begin{array}{l}\text { FFO } \\
(\text { RM'm) }\end{array}$ & $\begin{array}{l}\text { Leverage } \\
(\mathrm{RM} \text { 'm) }\end{array}$ & $\begin{array}{l}\text { Asset Value } \\
\text { (RM'm) }\end{array}$ & $\begin{array}{l}\text { Dividend } \\
\text { (Sent) }\end{array}$ & $\begin{array}{l}\text { Predicted } \\
\text { Dividend (Sen) }\end{array}$ & $\begin{array}{l}\text { Predicted } \\
\text { Yield (\%) }\end{array}$ \\
\hline AmFirst REIT & 2008 & 1.03 & 381.81089 & 31.313 & 396.6 & 836 & 7.3 & 7.37251922 & 8.283729461 \\
\hline \multirow[t]{4}{*}{$\mathrm{IPO}=\mathrm{RM} 1$} & 2009 & 1.325 & 373.23087 & 37.537 & 402 & 980 & 8.75 & 9.21892226 & 10.59646237 \\
\hline & 2010 & 1.3535 & 364.65085 & 41.915 & 413 & 1,008 & 9.75 & 9.4533308 & 11.12156565 \\
\hline & 2011 & 1.3631 & 471.9011 & 41.75 & 407 & 1,024 & 9.75 & 9.3070993 & 8.460999364 \\
\hline & 2012 & 1.3917 & 497.64116 & 39.994 & 550 & $1,179.84$ & 9.31 & 9.55833018 & 8.23993981 \\
\hline $\begin{array}{c}\text { AmanahRaya } \\
\text { REIT }\end{array}$ & 2008 & 1.0198 & 315.0338294 & 67.06631 & 253 & 686.332 & 7.0105 & 7.549915497 & 10.34235 \\
\hline \multirow[t]{4}{*}{$\mathrm{IPO}=\mathrm{RM} 0.94$} & 2009 & 1.0198 & 381.924574 & 30.87731 & 253 & 686.332 & 7.1549 & 7.162811036 & 8.093571792 \\
\hline & 2010 & 0.9744 & 535.9605672 & 41.4008 & 362.96528 & 913.617 & 7.4398 & 6.903037459 & 7.382927763 \\
\hline & 2011 & 1.0496 & 521.6300708 & 73.69232 & 363.26067 & 944.76 & 7.22 & 7.607370091 & 8.359747353 \\
\hline & 2012 & 1.0586 & 527.3622694 & 46.88661 & 363.55606 & 952.476982 & 7.4487 & 7.466067727 & 8.115291008 \\
\hline Starhill REIT & 2008 & 1.1878 & 1061 & 20.104 & 180 & $1,529.66$ & 6.8936 & 7.507499 & 8.341665555 \\
\hline \multirow[t]{4}{*}{$\mathrm{IPO}=\mathrm{RM} 0.9$} & 2009 & 1.1662 & 1007.95 & 18.268 & & $1,550.33$ & 6.65 & 7.501213 & 8.773348538 \\
\hline & 2010 & 1.1508 & 1037.422222 & 13.538 & 180 & 494.7 & 5.72 & 6.267823555 & 7.122526767 \\
\hline & 2011 & 1.1443 & 1172.526667 & 51.62 & 180 & $1,611.51$ & 7.23 & 7.344822166 & 8.299234086 \\
\hline & 2012 & 1.1165 & 1364.635556 & 16.81 & $1,489.43$ & $1,570.41$ & 6.32 & 6.521131389 & 6.331195523 \\
\hline Benchmark & & & & & & & & 7.78279285 & 8.5243037 \\
\hline
\end{tabular}

Note. REIT return forecast (in Sen and \%) using hedonic regression model.

\section{Discussion of Findings}

From the data presented in Table 2, it is clear that none of the independent variables have one direction of influence on yield. For the AmFirst REIT, NAV increased throughout the period of study while the dividend increase, get static and decrease. Despite the decrease in capitalization between 2008 and 2010, dividend increases and with increase in capitalization between 2011 and 2012, dividend falls. The same situation goes for leverage and FFO. Consistently increase in asset value corresponds with increase in dividend except in 2012. In case of AmanahRaya, dividend increases up till 2010 despite a decrease in NAV in 2010 and a fall in dividend in 2011 despite increase in NAV in the same year. The dividend could be said to be moving in the same direction with size but a fall in size in 2010 could not prevent a rise in dividend. Despite fall in income, dividend continues to rise. The marginal rise in leverage is greeted with rise in dividend as well over the period under study. Again increase in asset value leads to increase in dividend. Starhill exhibited a consistent fall in NAV but inconsistent changes in dividend, so also is the size. However, the movement of income and divided is direct though may not be proportional. Practically leverage has no effect on dividend for Starhill REIT. The relationship between asset value and dividend is non-proportionally direct. 
Table 2 also reflects and confirmed the mixed findings of previous studies on effect of each independent variable on dividend. While some agreed that NAV contributes to the return on direct proportionate way (Ong et al, 2011), others said that NAV is a product of "Noise" and investors sentiments (Clayton, Eighholtz, Geltner, \& Miller, 2007; Clayton \& Mackinnon, 2001; Young, 1998). The regression returns a positive and significant relationship between return and NAV and in agreement with Ong et al., (2011). The effect of size had also been with conflicting report. In this study, AmFirst is the least capitalized but with the highest dividend over the period under study, while Starhill the highest capitalized have the minimum yield. This confirmed the position of Yong et al. (2009) that the smaller the size the higher the return but contradicted Alias and Soi Thoi (2011) and Ambrose and Linneman (2001) that stated positive relationship between size and return. This study with the significant negative beta value (-0.002) and $\mathrm{P}$ value of 0.002 affirmed the negative relationship between size and return. The study also confirmed the FFO instability effect on dividend (Feng, Price, \& Sirmans, 2011; Hwa \& AbdulRahman, 2007; Gore \& Scott, 1998). (Bradley, Capozza, \& Seguin, 1998) concluded a negative relationship between cash flow volatility and dividend level. Leverage has no significant effect on REIT dividend as exhibited by table 7 and the regression result of this study. Despite increase in asset value, there were no proportionate increase in dividend, the regression also show no significant relationship between asset value and dividend. We therefore state that only NAV and Size are predominant predicting variables of REIT return. On the simultaneous effect, the study found that all the variables jointly and significantly contribute up to $91.7 \%$ of REIT return $\left(\mathrm{R}^{2}=0.917\right)$ and $\mathrm{P}$ value $=0.000125$. We therefore accept our postulation that the variables studied have simultaneous effect on REIT. The regression is validated with the residual value of 1.74 and mean square error of 0.193 indicates that the result is within allowable error at $95 \%$ confidence level. The regression forecast a REIT return of $8.5 \%$ for 2013 which is higher than the $6.26 \%$ achieved as at September 2013 . There is no pointer that the REIT return will surpass the predicted benchmark in the remaining last quarter of the year.

\section{Conclusion}

The findings of this study confirmed the position in this paper that all the independent variables have influence on the dividend at the same time (simultaneously) and no variable should be considered individually and in isolation of others to reveal the true performance of REITs. The study also found that REIT performance is below the predicted benchmark of $8.5 \%$. However, when compared with other benchmark (KLCI or KLPI), it outperformed the market. Comparing the REITs return of September 2013 which was $6.26 \%$ with September KLCI of $5.3 \%$, REITs outperformed the KLCI but below the 2013 predicted return of $8.5 \%$ for the REIT sector. It could be concluded therefore that M-REIT outperforms the KLCI but have a sectoral capacity underperformance. From this study, benchmarking REITs with market indices/indexes will not reveal the true (maximum) potential of REITs. We recommend a simultaneous analysis of factors determinant and setting of REIT benchmark from the sector past performances in other to achieve optimum return.

\section{References}

Ahmad, M., \& Izah. (2010). Empirical Investigation on the Performance of the Malaysian Real Estate Investment Trusts in Pre-Crisis, During Crisis and Post Crisis Period. International Journal of Economics and Finance.

Alias, A., \& Soi Tho, C. Y. (2011). Performance Analysis of REITS: Comparison between M-REITS and UK-REITS. Journal of Surveying, Construction and Property, 2.

Allen, M. T., Madura, J., \& Springer, T. M. (2000). REIT characteristisc and the sensitivity of REIT returns. Journal of Real Estate Finance and Economics, 21(2), 141-152. http://dx.doi.org/10.1023/A:1007839809578

Ambrose, B. W., \& Linneman, P. D. (2001). REIT Organisational Structure and Operating Characteristics. Journal of Real Estate Research, 21(3), 141-162.

Amidu, A., Aluko, B. T., Nuhu, M. B., \& Saibu, M. O. (2008). Real estate security and other investment assets. Journal of property Investment and Finance, 26(2), 151-161. http://dx.doi.org/10.1108/14635780810857890

Banz, R. W. (1981). The Relationship Between Return and Market Value of Common Stocks. Journal of Financial Economics, 9, 3-18. http://dx.doi.org/10.1016/0304-405X(81)90018-0

Bradley, M., Capozza, D. R., \& Seguin, P. J. (1998). Dividend Policy and Cash-Flow Uncertainty. Real Estate Economics, 26(4), 555-580. http://dx.doi.org/10.1111/1540-6229.00757

Brounen, D., \& Sjoerd, D. K. (2012). Review articles: 50 yeras or real estate investment trusts: an international examination of the rise and performance of reits. Journal of Real Estate Literature, 20(2), 197-223. 
Camp, R. C. (1989). Benchmarking-The Search for Industry Best Practices that lead to Superior Performance. Milwankee, WI: ASQS Quality Press.

Chaudhry, M. K., Maheshwari, S., \& Webb, J. R. (2004). REITs and idiosyncratic risk. Journal of Real Estate Research, 26(2), 207-222.

Clayton, J., \& Mackinnon, G. (2001). The Time-Varying Nature the Link between REIT, Real Estate and Financial Returns. Journal of Real Estate Portfolio Management, 7, $43-54$.

Clayton, J., Eighholtz, P., Geltner, D. M., \& Miller, N. G. (2007). Commercial Real Estate Analysis and Investments. International Student Edition (2nd ed.). USA: South-Western.

Coulson, N. E., \& Robin, M. L. (2001). The Internal and External Impact of Historical Desgnation on Property Values. Journal of Real Estate Finance and Economics, 23, 113-124. http://dx.doi.org/10.1023/A:1011120908836

Court, A. T. (1939). Hedonic prices indexes with automobiles examples in The Dynamic of Automobile Demand. New York: General Motors.

Delcoure, N., \& Dickens, R. (2004). REIT and REOC systematic risk sensitivity. Journal of Real Estate Research, 26(3), 237-254.

Feng, Z., Price, S. M., \& Sirmans, C. F. (2011). An Overview of Equity Real Estate Investment Trusts (REITS): 1993-2009. Journal of Real Estate Literature, 19(2), 307-343.

FMI. (2010). Real Estate Investment Trusts: Is the Philippines Ready? Capital Research: FMI.

Goodman, A. C. (1998). Andrew Court and the Invention of Hedonic Price Analysis. Journal of Urban Economics, 44(2), 291-298. http://dx.doi.org/10.1006/juec.1997.2071

Gore, R., \& Stott, D. M. (1998). Towards a More Informative Measure of Operating Performance in the REIT Industry: Net Income vs. Funds From Operations. Accounting Horizons, 12(4), 323-339.

Green, R. K., \& Malpezzi, S. (2001). A Primer on US Housing Markets and Policies. The Urban Institute Press for American Real Estate and Urban Economics Association.

Grinblatt, M., \& Titman, S. (1993). Performance Measurement without Benchmarking: An Examination of Mutual Fund Returns. Journal of Business, 66(1), 47-68. http://dx.doi.org/10.1086/296593

Grupe, M. R., \& DiRocco, C. J. (1999). The NAREIT index of REIT industry performance. Real Estate Finance, 16(1), 21-50.

Hamelink, F., \& Hoesli, M. (2004). What factors determine international real estate security returns. Real Estate Economics, 32(3), 437-462. http://dx.doi.org/10.1111/j.1080-8620.2004.00098.x

Hoesli, M., \& Lizieri, C. (2007). Real Estate in the Investment Portfolio. A report for the Investment Strategy Council (pp. 94-95). Norway: Ministry of Finance.

Horvath, P., \& Herter, N. R. (1992). Benchmarking: Comparison with the best of the best. Controlling, 4(1), 4-1.

Hwa, T. K. (2008). Sources of Net Present Value Gains In The Acquisitions of Corporate Real Estate. Journal of Corporate Real Estate, 10(2), 121-129.

Hwa, T. K., \& Abdul Rahman, M. Y. (2007). Stability of Dividends and FFOs: The Case of REITs in Malaysia. Paper presented at the 13th Pacific Rim Real Estate Society Annual Conference, Perth, Australia. http://dx.doi.org/10.1108/14630010810905624

Keim, D. B. (1983). Size-related Anomalies and Stock Return Seasonality: Further Empirical Evidence. Journal of Financial Economics, 12, 13-32. http://dx.doi.org/10.1016/0304-405X(83)90025-9

Kouzmin, A., Loffler, E., Klages, H., \& Korac-Kakabadse, N. (1999). Benchmarking and performance measurement in public sectors: Towards learning for agency effectiveness. International Journal of Public Sector Management, 12(2), 121-144. http://dx.doi.org/10.1108/09513559910263462

Lee, C. F., \& Kau, J. B. (1987). Dividend Payment Behaviour and Dividend Policy on REITs. Quarterly Review of Economics and Business, 27, 6-21.

Mclntosh, W., Liang, Y., \& Tompkins, D. L. (1991). An Examination of the Small-firm Effect Within the REIT Industry. Journal of Real Estate Research, 6, 9-17.

Newell, G., Ting, K. H., \& Archeampong, P. (2002). Listed Property in Malaysia. Journal of Real Estate Literature, 10, 109-118. 
Olgun, F. S. (2005). The performance of aquisitions in the real estateinvestment trust industry. The Journal of Real Estate Research, 27(3), 321-342.

Ong, T. S., The, B. H., \& Chong, M. P. (2011). A Study on the Performance of Malaysian Real Estate Investment Trusts from 2005-2010 by using Net Asset Value Approach. International Journal of Economics and Research, 2(1), 1-15.

Oxley, M., \& Smith, J. (1996). Housing Policy and Rented Housing in Europe. London: Spon.

Ratcliffe, C., \& Dimowski, B. (2007). The responsiveness of LPT returns and their attributes. Pacific Rim Property Research Journal, 13(3), 280-297.

Sheppard, S. (1999). Hedonic Analysis of Housing Markets. In P. C. Chesire \& M. Edwin S (Eds.), Handbook of Regional and Urban Economics (3rd ed.). Elsevier.

Ting, K. H., \& Mohd. Y. A. R. (2007). Stability of Dividend and FFOs: The Case of REIT in Malaysia. Paper presented at the 13th Pacific RIM Real Estate Society Annual Conference, Fremantle, Perth, Australia.

Wallace, H. A. (1926). Comparative farmland values in Iowa. Journal of Land and Public Utility Economics, 2(October), 385-392. http://dx.doi.org/10.2307/3138610

Yong, J., Allen, D. E., \& Lim, L. K. (2009). AREIT returns from 1990-2008: A multi-factor approach. Paper presented at the 18th World IMACS/MODSIM Congress, Australia.

Young, J. G. (1998). Determinants of Reit Franchise Value. Real Estate Review, 28(4).

Young, S. (1993). Checking performance with competitive benchmarking. Professional Engineering, 14-15.

\section{Copyrights}

Copyright for this article is retained by the author(s), with first publication rights granted to the journal.

This is an open-access article distributed under the terms and conditions of the Creative Commons Attribution license (http://creativecommons.org/licenses/by/3.0/). 